\title{
Unveiling and Subverting Hidden Meanings: The Sari as a Creative Tool in Designing a Woman's Identity in Shakuntala Boolell's "La femme enveloppée" (1996)
}

\author{
Olga Barrios \\ Faculty of Philology, University of Salamanca, 37008, Salamanca, Spain \\ *Corresponding Author: barrios@usal.es
}

Copyright $@ 2014$ Horizon Research Publishing All rights reserved.

\begin{abstract}
Supaya, the protagonist of Indo-Mauritian writer Shakuntala Boolell's nouvelle "La femme enveloppée" (The Wrapped-Up Woman, 1996), rejects the sari throughout the years of her childhood as a dress that oppresses women. However, after being forced to marry at 12 and with the passage of time, she transcends oppression and uses her sari and silence as tools and space for self-discovery. I will show how Supaya, rather than allowing the sari to imprison her, will subvert the original meaning of oppression conveyed by her garment and find the necessary freedom to construct her own identity. Paralleling Supaya's reversal of attitude towards her sari and by writing "La femme enveloppée", Boollel equally subverts the traditional Indian woman's image by "rescuing her dignity and strength." (Pereyra and Mora 189) [1] In this essay I will first examine the origins and various meanings of the sari and briefly compare and contrast this Indian attire to other veil clothing imposed on women in Muslim societies. Secondly, I will ponder whether a feminist reading of Boolell's story is possible. And, finally, I will analyze Supaya's evolution from her original rejection of the sari as a symbol of oppression to new readings of it - as a device of resistance against confinement and as a symbol of creativity in the construction of her identity - something that will help appreciate the complexity and further meanings encountered in this Indian traditional attire.
\end{abstract}

Keywords Sari, Indian Women'S Traditional Attire, Shakuntala Boollel, Indian Diaspora, Indian Women's Literature, Women's Subverting Symbols Of Oppression, Indo-Mauritian Literature

\section{Introduction}

Clothing seems to play an important function in the individual's construction of identity. To demonstrate this fact, Emma Tarlo wrote her book Clothing Matters: Dress and Identity in India (1996) so that she could "reveal the active role that clothing has played in the identity construction of individuals, families, castes, regions and nations." (1) [2] Clothes should be taken and examined carefully for they play an important role in determining an individual's image and personality: "Clothes are frequently perceived as expressions and even extensions of the people who wear them." (Tarlo 17) [3] Tarlo goes even further into how clothes may be taken as an identifier of a person's nationality. Paraphrasing Nirad Chaudury, [4] she claims that clothing, like language, "confers the wearer a distinct mark of nationality and culture." (Tarlo 17) [5] However, Tarlo adds that "[while] clothes may at times express 'cultural allegiance', this depends on the attitude of the wearer to his or her clothes. Just as clothes can challenge social and political norms as much as they uphold them ... so they can conceal identities as much as they reveal them ...." (17) [6] In this essay I intend to show the complex dialectics established between an Indian woman and her Indian sari, examining her shifting attitude from rejecting this attire to worshipping it as a sacred cloth.

Supaya, the protagonist in Indo-Mauritian writer Shakuntala Boolell's nouvelle "La femme enveloppée" (1996), rejects the sari throughout the years of her childhood as a dress that oppresses women. However, after being forced to marry at 12 and with the passage of time, she transcends oppression and uses her sari and silence as tools and space for self-discovery. I will show how Supaya, rather than allowing the sari to imprison her, will subvert the original meaning of oppression conveyed by it and find the necessary freedom to construct her own identity. Paralleling Supaya's reversal of attitude towards her dress and by writing "La femme enveloppée", Boollel equally subverts the traditional Indian woman's image by "rescuing her dignity and strength." (Pereyra and Mora 189) [7] In this essay I will first examine the origins and various meanings of the sari and briefly compare and contrast this Indian attire to other veil clothing imposed on women in Muslim societies. Secondly, I will ponder whether a feminist reading of 
Boolell's story is possible. And, finally, I will analyze Supaya's evolution from her original rejection of the sari as a symbol of oppression to new readings of the garment - as a device of resistance against confinement and as a symbol of creativity in the construction of her identity - something that will help appreciate the complexity and further meanings encountered in this Indian traditional attire.

\section{Origins and Meanings of the Sari}

The word sari is a corrupted version of Sanskrit word satsi that means strip of cloth. This traditional dress that continues to be used by many Indian women in and out of India is a fabric that ranges in size between 5 to 9.5 yards and is loosely tied, folded and pleated. Saris can be draped in different ways depending on the various regions of India. There are different motifs that can be found in saris and each of them symbolizes something different. Colours also convey different meanings depending on the occasion they are worn. Wearing and draping a sari is considered an art. Saris can be made of silk or cotton fabrics and, originally, were hand-woven as artistic pieces for women to wear. Nowadays, a great number or saris are woven on mechanical looms and made of artificial fibres-polyester, nylon, rayon-but hand-woven saris are still available. The sari developed as a garment of its own in South and North India at around the same time and is considered a symbol of Indian culture. Archaeological fact dates the sari back to the Indus Valley Civilization (2800-1800 BC) "around the western part of the Indian subcontinent." (Gnaana) [8]

Emma Tarlo emphasizes the fact that clothes have been used to "assert power, challenge authority, conceal identity, and instigate or prevent social change throughout Indian society from the village to the nation." And during the late nineteenth century in India the use of a style that incorporated Western elements into their clothes was questioned. The discussion culminated with Gandhi's adoption of the loincloth to contrast Indian poverty to British wealth. (Tarlo Back Cover) [9] In the same line, the maintenance of the sari remains as a clear sign of Indian national identity.

As very traditional attire, the sari conveys a deep meaning around several Hindu beliefs, among them that due to the use of needles of bone stitched clothes were considered impure; the navel is a source of life and creativity which explains why the midriff is left bare when wearing a sari; and the ancient Indian concept of women's beauty consisted on a thin waist and large bust and hips and the sari perfectly accommodated to emphasize these parts of the woman's body. (Sari History through the Ages) [10]

Taking those beliefs into account, the sari made women look "more feminine, while covering her body from head to toe, exposing the waist of a woman, emphasizing the waist and bust and yet making a woman look modest and coy." The sari is also believed to be a fabric that is "pure and sacred" (Sami) [11] and, after Indian's independence from Great
Brittan, it became the emblem of national unity and identity with the purpose of being loyal to the nation. (The Sari Meanings behind the Cloth) [12] Palash R. Gosh, on the other hand, focuses on the fact that the sari was originally intended to keep teenaged girls and women "both comfortable in the heat and to look 'modest"' but equates the sari's function to that of the Islamic burqa in that it was “designed to 'hide' a woman's figure and curves in order to prevent the unwanted attention of men (and, by extension, a sexual assault)," adding, though, that this has not "prevented millions of Indian men from bothering women over the centuries. (Gosh) [13] Gosh's observation offers a different perspective to that of the sari being made to accentuate women's curves. It is precisely Gosh's view that connects more closely with the idea of Supaya's rejection of the Indian attire during her childhood as a dress made for the oppression of women; whereas Supaya's reversal of attitude in her adulthood approaches the original idea of the sari as a sacred cloth that has helped modelled her identity throughout the years.

Palash R. Gosh's digression on the function of the sari in regard to men takes me to the practising of veiling/purdah in Muslim and some Hindu communities. According to the Oxford Dictionary, purdah is defined as "the practice in certain Muslim and Hindu societies of screening women from men or strangers, especially by means of a curtain." (Gosh) [14] This curtain is referred to sometimes also as the veil worn by women that conceals them from the sight of men. In the second page of Boolells' nouvelle, Supaya as a child shouts: "I will never bury myself in your purdah. I am not a scrawny plant. I will go and warn my sisters from door to door against discriminations." (191) [15] Therefore, purdah, which is equated with veiling, occupies an essential place in this story from the very beginning. Following is a quite descriptive extract of how Indian women comply with purdah when they leave their homes:

Women effectively take their walled courtyards with them when they venture out in a veil. It is a logical supplement to the use of enclosed living spaces and enables women to move out of these spaces in a kind of portable seclusion. The usual way of observing purdah in the village is by a strict dress code where the head and breasts are covered by a piece of cloth or the end of the sari, often pulled forward to obscure the face - this is known as ghungat. If a woman must go out to work on the fields or to fetch water, her demeanour is so reserved, that it is as effective as wearing a burqa. (Purdah and Rural Housing in South Asia) [16]

The first sentence of this quotation clearly draws a parallel between seclusion and the use of the veil for women when leaving their homes, and they take "their walled courtyards with them." Furthermore, we learn that Indian women may avoid using an extra cloth since the end of the sari or pallav can be used as a veil.

The question one may ask is why women veil in some regions of India and do not contemplate abandoning this custom; whether they maintain this custom for religious or social reasons. Emma Tarlo, intrigued by this issue, decided 
to study several regions, among them the village of Jalia in the Amreli District of Gujarat region, and has concluded that veiling in that village is associated not only with behaviour but also with emotions for veiling is associated with shame and modesty. Veiling can be considered simply "an expression of the female feeling of shame of embarrassment.' (164) [17] And since feelings of shame, shyness and/or modesty are "natural and obligatory for women", the practice makes the use of the veil to seem natural. Consequently, this prevents women from questioning the custom and they simply "encourage and uphold it." (Tarlo 165) [18]

Among other implications conveyed in veiling is the fact that it structures relations between men and women and also become a means of expressing "different levels of social refinement". Furthermore, the way a woman dresses is linked not so much to her biological development as to her "social role, especially in relation to men." For instance, whereas for men the transition from son to husband is considerably gentle, for women the shift from daughter to wife is quite drastic and women can never play both roles simultaneously. (Tarlo 159) [19] Once married, women abandon their native village as daughters and go to live as wives (and later mothers) to their conjugal home with their in-laws. Veiling for these women, then, becomes not only "a refuge from the prying eyes of strangers,. . . but ... also a means of gaining approval from her new in-laws." (Tarlo 166) [20] This radical adjustment from daughters to wives/mothers confers Indian women a dual aspect of their identity marked by veiling restrictions. (Tarlo 59) [21] This is exactly the situation that Supaya experiences in the story narrated by Boolell. After marrying, Supaya moves with her husband to the home of her in-laws and it is there where she will have to observe the rules of veiling and will subvert the original meaning of oppression that she had originally perceived when being a child. Veiling, then, seems to be a means of both "maintaining and creating the reputation of a woman, her family and her caste and this encourages women to uphold the custom." (Tarlo 166) [22]

Sarohini Sahoo contributes with another piece of information as to when the veil was introduced in India, for this is not part of Indian traditions:

In South Asian and Southeast Asian countries, any type of veil for women was not in tradition. In 1994, the Malayasian Supreme Court said in a historic ruling that any type of veil or purdah, "has nothing to do with (a woman's) constitutional right to profess and practice her Muslim religion, because Islam does not make it obligatory to cover the face." (Sahoo) [23]

Sahoo adds that it was later, during the rise of Muslim conservatism, that the religious fundamentalists introduced burqa (a concealing cloak) and hijab (Islamic veil to cover a woman's head). However, Sushila Sing, a professor at Banaras Hindu University in Varanasi, observes that although purdah is a cultural practice that requires women to observe it by wearing burqa, only Islamic women wear it but Hindu women do not. Singh also underscores that purdah originated in Islamic cultures but is an alien phenomenon to Hindu women. With the Muslim invasions, though, the purdah system was introduced for Hindu women to practice. However, Singh adds that "although this system was established for the protection of Hindu women just as it protects Islamic women, this purdah took a different form [and] veiling one's face, or goonghat [or ghunghat], came into practice." (Lifting the Veil) [24] An example of observing purdah in India is that men usually announce their presence with a warning cough before entering a room so that the woman can "crouch on the floor drawing her sari over her head." (Lifting the Veil) [25] Burqa and hijab, therefore, have not been adopted as they have been in countries of majority Muslim population.

Furthermore, if there is a dual aspect of Indian women's identity marked by the restrictions of veiling as observed by Emma Tarlo, veiling also offers various readings when applied to Indian women's identity. On the one hand, the cloth is in almost constant motion "being drawn, adjusted, withdrawn and redrawn in such a variety of ways that it seems almost alike a part of the female body ... [and] she must move her veil with the same self-consciousness that she moves her body." (160) [26] Therefore cloth and body seem to become one. On the other hand, if veiling is considered a way of seclusion, it can also become an "extension of the female space and a portable means of maintaining the possibility of shifting from the public to the private sphere any moment." (Tarlo 160) [27] In Boolell's nouvelle, Supaya runs from her original reading of purdah/the sari as seclusion to using it as a private and nourishing space from which to construct and shape her identity. Therefore, Supaya's sari broadens its symbolism of seclusion into that of a free and private space that allows her self-discovery and construction of her identity.

\section{3. "La Femme Enveloppée": a Feminist Reading of Traditional Indian Sari?}

Before going into a closer analysis of the story, I must say that "La femme enveloppée" by Indo-Mauritian writer Shakunta Boolell is one of the mandatory readings for a course called "Women, Literature and Postcolonialism" that I teach in a Master of Multidisciplinary Gender Studies. Boolell's story has always generated passionate debates among my students (and myself) as to how women can promote and/or accept the use of veil (even if those veiled women themselves want to be veiled), which my students have concluded is the moral of the story. We have argued whether this can be regarded as a feminist position or if it should be left completely out of any feminist approach. However, Boolell's nouvelle-in spite of its short length - poses complex issues that require deep consideration and a meticulous evaluation (especially Western feminist positions) and I believe contributes to enrich and expand feminist theories. Therefore, I would like to postulate briefly a few thoughts upon which I will contend 
my analysis of the text from a feminist perspective.

In her book Sub-versive Women: Women's Movements in Africa, Asia, Latin America and the Caribbean, Dutch feminist scholar Saskia Wieringa explores the political dimensions of the word feminism:

Recognizing the political dimension of the word "feminist" offers some scope to locate the concept within its historical context: What may be called "feminist" in one historical period or in one particular political setting, need not be called "feminist" in another . Most contemporary feminists would agree that feminism is not a one-dimensional social critique, but a multi-layered, transformational, political practice and ethics. The transformation is towards feminization and democratization on domestic, social and political levels, as well as towards economic levelling and an end to racial discrimination. (3-4) [28]

I am especially interested in highlighting her definition of feminism as a "multi-layered, transformational, political practice and ethics," since this definition includes rather than exclude the differences existing in the multiple experiences of women all over the world that must examined in their specific socio-political context. Following this line, Wieringa concretely focuses on the contradictory and complex connotations embedded in the experiences of women in previously colonized and now independent countries and how Western and Indigenous forms converge in their lives:

The colonial experience and the racialization and sexualisation of the colonized peoples had far-reaching, contradictory and complex implications for women. Indigenous forms of women's subordination intersected with the new colonial ideology which further entrenched women in a domesticated, sexually subservient position. The emphasis on motherhood and domesticity of women in the Victorian, European societies was carried by the colonial powers into their overseas dominions. (17) [29]

Wieringa acknowledges not only possible discriminatory and sexist indigenous traditions in colonized countries but also sexist and discriminatory practices that were equally carried and imposed by colonizers. In addition, she points out that the strength of Third World feminism lies in "its insistence on the materiality of power relations, not only in cultural practices, but in all aspects of daily life" and advocates for international solidarity among women on the basis of "respect for each other's identities, struggles and analytical positions." (19) [30] I concur with Wieringa in that it is absolutely necessary to achieve international solidarity built upon respect to our differences when analyzing women's experiences in regions other than our own.

Feminist theory has been constructed upon the experiential discriminations suffered by women throughout history. However, since women's lives change and fluctuate depending on their social, cultural and personal situations, feminist theories should not be monolithic and one-dimensional but a "discursive process," (5) [31] as Wieringa has highlighted. When analysing women's conditions from a feminist perspective, then, I believe we must analyze those everyday life experiences within their specific context rather than trying to study how women's behavioural patterns conform to the already established feminist theories. As stated by feminist scholar Teresa de Lauretis, feminism "defines itself as a political instance, not merely a sexual politics, but a politics of experience, of everyday life, which later then in turn enters the public sphere of expression and creative practice. "(10) [32] Furthermore, De Lauretis underscores that feminism has located "epistemological priority in the personal, the subjective, the body, the symptomatic, the quotidian, as the very site of material inscription of the ideological." (11) [33] This personal and subjective focus on feminist studies is what must be understood when analyzing the character of Supaya in Boolell's literary story, for feminism, is "located both in the public outburst and in struggles in the private domain, for these private struggles are always expressions of the external collective processes." (De Lauretis 5) [34] Boolell's story precisely shows the silent struggle of a woman in an oppressive environment behind her sari and veil.

When analyzing "La femme enveloppée" my intention is to do it from the feminist perspective contemplated by Saskia Wieringa, that is to say, feminism as "tied up with such issues as transformative processes, the shifting and unstable concept of 'woman' itself and women's identity and consciousness." (5) [35] In order to produce any transformations in our lives, I believe awareness is the first step (also a tool provided by feminism) that need be taken, as stated by Indian scholars Kamla Bhasin and Nighat Said Khan in Feminism and Its Relevance in South Asia (1986): "Feminism is an awareness of women's oppression and exploitation in society, at the place of work and within the family and conscious action to change this situation." (3) [36] Supaya's awareness of the oppression suffered by her "Indian sisters" is reflected at the very beginning of the story but she cannot fight alone and produce social changes in her village so she subverts the same tools created to oppress her and uses them to create her own private space from which she feels free to construct her own identity. Supaya's inner journey might be regarded as the specific feminist process "of producing meaning, of subverting representation of gender and creating new representations of womanhood, of identity and the collective self," (5) [37] as stated by Wieringa.

Actually, in spite of remaining hidden and silent behind the sari, Supaya stays in control of her self and her body, something that Linda Lowen emphasizes as an essential issue: "I believe in the theory that 'a woman's body is a woman's right'. By that I mean that women should control their bodies and men should take them seriously." (Lowen)[38] With the passage of time, as an elderly woman, Supaya's elegant and unique way of walking and wearing her sari had aroused the admiration of other women: "Tell us, Supaya, you are too perfect a mannequin. What is your secret?" And Supaya replied: "Perhaps the fact of having become aware of the short distance that exists between my 
sari and myself." (Boolell 191) [39] Then the narrator adds: "It was true. Nobody could stand between her and her sari. Wearing it daily granted her an acute awareness of her identity." (Bollel 195) [40] The ending of the story is open to various readings. The accepting and idolizing of her sari might be interpreted as Supaya's appropriation of the sari or as the sari's appropriation/confinement of Supaya, something that will be discussed in the following analysis of Boolell's text.

\section{Supaya's Creative and Transformative Process in Defining Her Identity}

"Le femme enveloppée" shows Supaya's conflicting oppressive society that limits women's freedom and forces them to either surrender or transcend oppression and achieve personal freedom and dignity - dwhile wrapped-up in a dress that paradoxically symbolizes female oppression. Although written in French, phrases in a vernacular are scattered throughout the whole text. The nouvelle tells the story of Supaya from childhood to elderly age. As a child Supaya always despised the sari for considering that it oppressed women, promising not to wear it ever in her life. However, with the passage of time after marrying at twelve by means of an arranged marriage and leaving her village to live with her husband and in-laws and was forced to wear a sari, her attitude towards her attire changed completely. In her new home and wearing her sari daily, she initiated an inner journey that took her to find new meanings embedded in the sari and in the use of silence. We would imagine the story takes place in the island of Mauritius [41] where Shakuntala Boolell was born and lives at present, but no indication from the author is given as to whether the backdrop of the story is India or another place outside India. The title of her book though clearly states that they are stories from Mauritius.

The situation of Indian women depicted in the story is that of their living under the confining religious precepts of purdah that only applies to the female population. Supaya refers to it straightforwardly: "I will never bury myself in your purdah." (Boolell 191) [42] Some of those moral precepts were "preached" (Boolell 192) [43] to girls at an early age as golden rules:

Cover your legs, come home at sunset, and worship Supreme God Shivji to have a good husband. Without that ... the minimum offense would draw the weaker sex in front of the repressive jury, essentially masculine. One should wrap up against all bad influence. A simple and happy solution." (Boolell 191) [44]

Apart from learning about Supaya's miserable existence as a child in an oppressive environment ruled my men, the narrator briefly tells the story of other three women (Sita, Parvati and Siva) who were severely punished for not responding appropriately to their husbands' demands, stating that "in the worst circumstance, woman would always get crippled." (Boolell 193) [45] When Supaya observed her environment and reflected upon women's conditions she used to think to herself: "The feminine universe means suffocating in the shade. In order to discipline it, this feminine world is interrupted in the middle of its games and desires." (Boolell 191) [46] These are a few examples that show how in the story women are completely dependent on the wishes of men and have no lives of their own.

However, as a child, Supaya seemed to be granted more freedom than the adult women around her. It must be noted that Indians as children are dressed very differently than when they are adults.

Childhood is the time when gender roles are least clearly delineated-also, interestingly, the only time when girls wear ready-made European-style clothes. In early childhood clothing is often minimal and not necessarily gender-specific; young girls are found wearing anything from skirts and dresses to shorts and vests like their brothers. Girls and boys play freely together and there is little to distinguish between them except for the ring in the girl's left nostril. (Tarlo 153) [47]

Emma Tarlo's description on Indian childhood clothes is important when taking into consideration Supaya's drastic reversal regarding her concept of the sari. As a child, Supaya loathed the sari for considering it an oppressive instrument for women. She probably looked at it from her perspective of wearing European-style clothes that gave her more freedom of movement. After being forced to marry and given a sari she must wear from then on she feels her freedom days are over: "Supaya's sad eyes reflected her defeat." (Boolell 193) [48]

One day when Supaya was twelve, after returning happily from school to announce a special prize she had been awarded in geography and arriving home "she was caught up by orders" and was suddenly requested to dress a yellow sari (colour representing asceticism): "She did not have time to understand what was going on; as if she were projected into a stage where she had to perform a role [although her story would not be taken] to the Indian screen." (Boolell 193) [49] She heard how her aunts enunciated a list of good things about her such as her being sweet and able to perform any domestic chores. The following days Supaya felt "locked up within her fears." Her aunts and uncles, and elder cousins had chosen a husband - Amar - who "did not wait too much to tie her up and take her to his world." (Boolell 193-194) [50] Supaya, however, with the years would stop complaining about oppression, transcending it by using her sari as a shelter that protected her from the hostile environment that surrounded her.

\subsection{The Poetics of the Sari: Unveiling Layers and Attributes}

As already stated a few pages earlier, Supaya used to say that she would never bury herself in purdah and would warn their Indian sisters against the discriminations they were suffering, to what an elder woman replied: "Who has taught you that language? Decent girls do not dream with independence." (Boolell 191) [51] Taking into account this 
situation, one could clearly see that Supaya would not conform nor resign to her future confinement and would find ways to surmount any walls built around her. Still a girl, Supaya was impatient to organize her life and imagined different scenes in her life as she despised that piece of cloth that wrapped up women from sunrise to night time:

She often boasted about being a modern person. There were rumours circulating about her being possessed by the devil when she threw her half veil far away and let her beautiful ebony long hair floating, making fun of the village women who mingled in their saris whose pleats masked their beautiful silhouettes. She believed that that piece of clothing that wrapped their bodies up from sunrise did not help women to feel comfortable. It was just a ritual required by the community. Women were wrapped up from the very moment they left their bedrooms. (Boolell 191) [52]

The narrator, though, will subtly keep unfolding the many layers and meanings that apply to the sari so that readers will be offered new attributes to the sari unknown to them. Among these attributes are the many rites associated with it as well as the many uses given to it by women. Thus, for instance, women seized the pallav (the final edge of the sari) or pallu all the time "to protect themselves from the prying looks of any nosy neighbour. In effect, whenever [Supaya's] mother left the family house, she accommodated her pallav upon her head as if it were a rein." (Boolell 192) [53] But at her early age Supaya could see the sari only as a cloth robbed women of their freedom, as she told her mother: "Don't you see that the sari guarantees our submission? Let's say that we leave it for a dress or a tight skirt, do you thing the community will become furious with us? Her mother secretly shuddered when hearing her concerns." (Boolell 192) [54] Supaya was unable to acknowledge and praise the many uses and functions elder women such as her mother, Manika, and her grandmother had encountered in their saris, a kind of portable space that provided women with a vast range of facilities:

It had been years since her mother had been wrapped up. Not only in thread, cotton and natural silk, but what is worse in beliefs and abominable prejudices. She was equally disguised in her inner drama. Nobody would have thought of it, but the sari was broad enough to hold woman's grief. In several occasions she had caught her mother drying up her tears with the pallav that she used to leave hanging upon her chest and belly. Her grandmother even blessed such a practical dress that saved them from using kitchen cloths and serviettes. [The sari even served women as a] key ring and $a$ purse." (Boolell 191. My emphasis) [55]

Supaya's mother could not understand why her daughter felt such "aversion for what was sacred." (Boolell 192) [56]. Time did prove that Supaya was wrong and little by little she began "to discard her ambitions to fight injustice" after realizing and acknowledging her impotence. (Boolell 192) [57]

Supaya's perception of women being locked up in their saris might be symbolically compared to the imprisonment of Nelson Mandela for more than twenty years in Robben
Island. During the years spent in jail, rather than admitting defeat, Mandela transcended those walls by using that time and space as an opportunity for self-discovery and strengthening his spirit, something that was clearly manifest when he was freed, elected President of South Africa, and awarded the Nobel Prize for Peace. Besides, as the ruler of South Africa, Mandela proved to be a compassionate man who adopted forgiveness rather than vengeance as the symbol of his authority to rule a divided population seriously wounded by the preceding regime of apartheid. The sari for Supaya or the prison for Mandela, both instruments and symbols of repression, did not annihilate their spirits. On the contrary, those walls reinforced and contributed to achieve inner freedom while following the constant process of constructing their identities. As Michele Cassou and Stewart Cubbley state, "[by] facing difficulties, you reveal yourself to yourself and the mystery unfolds." (Cassou and Cubley 109) [58] And it is the revelation of that mystery about her self that helped Supaya surmount her physical confinement and reach a deeper spiritual level. Supaya had subverted the meaning of the sari as an instrument of confinement into a space that granted her freedom, dignity and self-empowerment, all of which was actually revealed through the simple and elegant way the garment adapted to her body when wearing it. Actually, the sari transformed itself into a harbour from which Supaya could combat the oppressive environment that surrounded her. Therefore, Supaya's attitude had suffered a complete reversal from her concept of the sari as an oppressive cloth into the sari as a site that safeguarded her freedom.

Supaya's case clearly illustrates Saskia Wiering's concept of feminism as "a multi-layered, transformational, political practice and ethics." (3) [59] Wieringa's research has intended "to uncover ways in which women have been stretching the boundaries of social conventions with which they are confined, empowering themselves and acting in defence of what they perceive as their interests." (1) [60] Supaya's subversion of the oppressive meaning embedded in the sari upholds Katherine Bullock's theory extracted after reading the positive experiences Muslim women have shared in some newspaper articles: "The women's arguments derive from feminist critiques of the exploitation of the female body in capitalist society to contend that covering can be a form of liberation." (xxxix. My emphasis) [61] Against the hostile and monolithic view by Westerners in general and Western feminist in particular regarding the female Muslim veil and through the eyes of the women who wear that veil, Bullock intends to prove that other readings of the veil are possible. In the same line and through Supaya's transformation, Boolell's nouvelle equally illustrates that multiple readings apply to the sari. Apart from the possibility of the variety of meanings found in the veil and/or the sari, there is another consideration to be taken into account as pointed out by scholars Emma Tarlo (1996) and Bernard S. Cohn (1996) in their respective books. They have asserted that clothing may be both the site of authority and resistance to authority.

Supaya's relationship with the sari takes a completely 
drastic shift. "If when a child, she ridiculed the sari, the old woman that she had become idolized the attire of Indian women," we are told. "She had needed to go past the hard testing times of marriage, suffering and life to sign a peace agreement with the sari .... Were not the ancestors the ones who have given this beautiful cloth its attributes? They must have discussed this issue and concluded that it was necessary to get wrapped up." (Boolell 194) [62] Throughout the years, then, Supaya had come to terms with the sari considering it even beautiful. She realized that "[after] wrapping herself, her space had become tighter; her soul had limited the joy of life, noise and any other strong sensation. Again she left her imagination wander." (Boolell 194) [63] It seems that the effects the sari had on her reflected a change in a new attitude of life and thought more in agreement to her old age. The "tighter" space the sari had created around her had actually contributed to develop her imagination. Besides, if her mother and grandmother once listed the various uses they found in their saris to her as a child, Supaya as an elder woman had discovered new treasures attached to her Indian garment, among them its poetic value and the dignity it granted her as a member of her community.

Late, too late, Supaya had come to understand all the poetry of the sari. Apart from its civilized value in the Orient, the cloth that the Indian woman wore sharpened her sensitivity, purified her passions and aroused her dignity. Often she herself would have run to chase the rival that undermined her resistance of wife and mother. But was it not the sari that had withheld her? The sari had inspired her, on behalf of refinement and pride, not to become an outcast. They had even initiated a dialogue." (Boolell 194-195) [64]

"The sari," her mother had told her, "takes you to the service of a sublime ideal." (Boolell 195) [65] Consequently, Supaya's dress helped her achieve her sublime ideals against the social seclusion she daily experienced as a woman in a patriarchal environment.

\subsection{Subverting Oppression and Appraising New Meanings of the Sari}

The sari was conferred poetic and sublime attributes by Supaya in her journey towards the enlightenment she was able to attain with the passage of time for the sari had provided her with the opportunity to keep constructing herself as a woman:

Little by little, Supaya felt her spirit less confused. How much time to understand that the wrapped-up woman was just a woman veiled by secrets. No, she was not stupid but was illumined by her silence. For almost half a century her husband's licentiousness, her sister-in-law's rotten behaviour, her mother-in-law's insults had never emerged. Even when questions were asked, she dressed more and more beautiful. Thanks to the sari she had been a woman in perpetual construction." (Boolell 195) [66]

It was through that dialogue she had maintained with the sari for years that Supaya had discovered "unsuspected treasures that she would have never known otherwise. . ..
Nobody could stand between her and her sari." It was precisely the fact of her daily wearing the cloth that "gave her a sharp awareness of her identity." (Boolell 196) [67] Supaya's process illustrates Saskia Wieringa's words in regard to women's subversion of codes that limit their spaces and the need to acknowledge this fact:

The most striking finding was that women have been subverting the codes determining the spaces in which they move in many more creative and devious ways than we have ever imagined. We also discovered that the history of this subversion was continually being distorted and destroyed.

Women's acts of resistance, of self-affirmation, as social actors in their different historical and political contexts, are already in themselves subversive to existing power relations; but women have been "sub-versive" also in another sense: in circumventing, uncoding and denying the various, distinct and multi-layered verses in which their subjugation is inscribed and in replacing them with their own verses. Sometimes literally, at other times by creating their own cultures of resistance, re-shaping and transforming their surroundings. (1-2. My emphasis) [68]

Accepting and appraising the sari, does not mean that Supaya submits to the reality of oppression she is forced to live in. As indicated by Wieringa, Supaya has subverted old codes and given new meanings to a traditional cloth that she appropriated and made her own. Along her inner journey of self-discovery, Supaya resisted subjugation by creating her own language and her own private space, hence reshaping and transforming her position.

The characters of Boolell's story as members of a community-oriented village only count as long as they obey the community laws and usually have no say as individuals. However, Supaya is able to subvert another meaning of the sari: that of the sari as a cloth that, in spite of symbolizing the seclusion of women, must be worn by all women as a precept so that they will not become outcasts. By constructing a private space within her garment Supaya encounters and celebrates her own individuality, remaining faithful to her own thoughts and ideals while respecting communal and religious edicts that require wearing a sari. Supaya transgresses the oppressive rule intended for women to act like sheep and accept precepts without questioning them. Her community might wrap her up in a cloth but they cannot confine and limit her spirit or her thoughts, as a village woman observes in the film Moolaadé (2005)-by Senegalese filmmaker Ousmane Sembene: "The men want to lock our thoughts, but how can a thought be locked"? As stated earlier, Supaya's being faithful to herself and her community illustrates what Tarlo and Cohn have observed in regards to clothes; clothes can become the site of authority (Supaya's self-empowerment) and of resistance to authority (Supaya's resistance to erase her individuality/identity against communal laws). This dual function that serves both the individual and the community has also been observed by Hanna Papanek when referring to the female Islamic veil as symbolic shelter:

[The] view of life which is implied in the use of symbolic 
shelter is also one which sees individuals primarily in the context of their social units rather than as single individuals, architects of their own fate. At the same time, women who are sheltered become important demonstrators of the status of their protectors, and their behaviour becomes important in terms of honor and family pride for an entire kin group. (293) [69]

While wearing the sari as a shelter Supaya has been able to remain faithful to herself and to her community, for it is only when we touch and accept our inner self and singular identity that we will be able to be of service to our community.

Supaya also comes to understand why this Indian dress is regarded as a sacred garment. The attire she has been wearing daily has defended her against "any bad influence" (192) [70] as her mother had told her: "One degrades oneself by offering other the opportunity to criticize your appearance and your words. You know your worst shortcomings better than I. Your hatred, your violence, your pride come to surface quite often. You run a great risk. Your sari carefully covers what you live in your secrets." (195. My emphasis) [71] The sari had helped her develop a sense of self that she would not have discovered if she had kept resisting it and simply followed "verbal exchanges that mutilated" relationships among neighbours (190). Supaya's dress had made her understand the need to use it as a shield from the intrusion and abuse of others in order to keep her true self untouched. And only from that sacred space that her sari helped her preserve could she relate to others without losing her soul.

\subsection{Subverting Meanings Attributed to Age and Silence}

Shakuntala Boolell's nouvelle not only honours women's power and dignity in environments that oppress them and force them to silence; it also highlights the wisdom achieved by elder women, thus subverting the extended idea of valuing youth above old age. It is only after Supaya turns 50 that she acknowledges the effect exerted upon her by the sari and comes to understand a new and poetic dimension attached to it. Throughout the years, and wrapped up in her Indian sari, she has been compelled to think and feel and be in touch with herself. It is after this long process that she finally understands the multiple layers of meaning hidden within the sacred cloth. It is that wisdom she has acquired with the years that has become visible in the way she carries herself wrapped up by the sari. Supaya wonders whether she is happy at the age of 50, after being demonstrated "her fidelity, her virtue by submitting to the test of the sari?" and the narrator adds: "Her silence said a lot." (192-93) [72] Silence had especially helped her disclose new meanings through her inner quest.

The meaning of silence is also subverted in Boolell's story. In the history of women's discrimination and violation of human rights, silence has always implied the way women's voices have been usurped, mutilating their self-expression and, consequently, making them completely invisible and inexistent. However, Boolell shows another reading of silence that has to do more with spirituality and Asian religions and philosophies. The meaning of silence mutilating the existence of women is subverted into a silence that enlightens and grants Supaya access to the construction of her identity. The scholar Susan Bean has claimed that the communicative power of Mahatma Gandhi's loincloth "transcended the limitations of language." (qted. in Tarlo 18) [73] Similarly, Boolell also unveils ways that might contribute to improve our communication with the community and with ourselves beyond words: by means of the clothes we choose, the way we wear them, and/or by honouring silence.

"La femme enveloppée" highlights from the very beginning how the "verbal exchanges mutilated often the good neighbouring relationships" and how women, in a space separated from men, commented on new marriages, the miserable lives of some of them, and so on, but there was always an intended "malice" in all they said. Supaya, however, always remained silent, keeping an immutable face gazing into space. Wrapped-up in her sari, traditional dress that she had been wearing since she was 13 years old, when she abandoned her native village to follow the husband that they had imposed upon her, Supaya listened without saying a word." (190) [74]

At early age Supaya had been a very talkative girl and even "replied with insults to other girls" (191) [75], but throughout the years she had made the choice to remain silent, or simply had accepted silence and finally learnt why at school they were taught that "SILENCE [WAS] GOLDEN," always written in capital letters. Since then, "Supaya, had embedded those words in her soul. That silence - the emblem of so many wise people - was as sharp as a pair of scissors." (191) [76] Therefore, it seems that when she was a child, silence made her uncomfortable but with the passage of time Supaya came to unveil deeper meanings embedded in it, which had opened the door to self discovery and helped her transcend the rules that truncated her freedom.

\subsection{The Art of Silence in the Creative Process of Supaya's Gendered Identity}

Actually silence and solitude are two indispensable components for artists to develop their creative work: "For an artist, withdrawal is necessary. ... An artist requires the upkeep of creative solitude. An artist requires the healing of time alone. Without this period of recharging, our artist becomes depleted." (Cameron 97) [77] Supaya can be considered an artist and architect of her own life since she has not felt depleted with the years thanks to her continuous creation-construction-designing of herself. She had made a shield of her silence to protect herself from the external noise, abuse and mediocrity. In fact, it is precisely through silence that Supaya has been able to develop and sculpt her identity. It is also through that silence that she has been able to cope with her oppressive and dead environment consisting of people who seemed not to see beyond their nose. It is through 
silence that she has been able to establish her own inner and private space, transcend oppression, reach personal freedom and model her own gendered self as a woman. Saskia Wieringa refers to Teresa de Lauretis to explain particularly how our gendered identities might be constructed and how women become active creators in that process:

[A] gendered identity is never a simple given: subjectivity is always constructed through a continuous process in which we are not just passive recipients but also active creators of gendered power relations. Through a process of reflective practice, agency can be restored to individuals. According to De Lauretis the identity of a woman is the product of her own interpretation and reconstruction of her history, as mediated through the cultural discursive context to which she has access. (Wieringa 6. My emphasis) [78]

Supaya's story clearly illustrates the active role of a woman as creator of her own personality with the passage of time.

In Boolell's nouvelle the sari itself may also symbolize the chisel and brush given to Supaya to design and shape her identity. As already mentioned, Supaya herself had acknowledged that "thanks to the sari she had been a woman in perpetual construction." (195) [79] Sari and silence had contributed to induce Supaya into the creativity process necessary to the permanent construction of herself. The attire that was meant to hide Supaya's body turned actually into a cloth that, modelled by Supaya as a second skin by means of her introspection, ended up unveiling her true self. Accordingly, Boolell displays another function of the sari as a creative tool given to Indian women to construct and shape their unique selves. Each woman, then, will wear the sari in a particular way that reveals her own personality. This symbiosis between cloth and a woman's body is as ephemeral as any art form and as life itself. Once the piece of fabric has been removed from the woman's body the particular style is lost and the fabric reverts back to a flat rectangular form. Draping the sari is actually an art and an expression of a woman's creativity.

In the story, Supaya's mother tells her daughter that the sari is an "art of life" that "you devise yourself." (195) [80] Therefore, each woman is transformed into the creator of her own life. There is an Indian folk tale on the origins of the sari told by weavers to children that has to do specifically with the art of weaving:

The Sari, it is said, was born on the loom of a fanciful weaver. He dreamed about a woman. The shimmer of her tears. The drape of her tumbling hair. The colors of her many moods. The softness of her touch. All these he wove together. He couldn't stop. He wove for many yards. And when he was done, the story goes; he sat back and smiled and smiled and smiled." (The Sari: Mystery and Grace) [81]

It was believed that the weaving of this cloth was a metaphor for creation: "The thread was the foundation and the weaver was the architect or creator of the universe." (Gnaana) [82] Besides, the sari "represents religious and metaphysical connotations in Indian culture. The Kaurava's [83] inability to unwind the sari symbolizes the nature of infinity, whereas the weaver of the sari, or thread holder, is the architect of the universe." (Hoffman) [84] The metaphor of an endless cloth and a spiral is also a significant image that reminds of creativity itself for it contains endless paths that keep the artist in a continuous search of his or herself. [85] The fabrics used to make the sari are silk or cotton which are extremely soft to the hand touch. Originally all the saris were hand-woven (and many still are) which are artistic pieces for women to wear.

Finally, the story subverts another meaning of the sari, attire made to hide the woman's flesh (the physical part of the woman), turning it into a cloth than helps reveal or unveil a woman's soul, her true self, her identity. Each garment or piece of cloth might be taken as an interpretation of the self:

Clothing in most (if not all) cultures is a significant interpretation of the self. It says something about who we are or at least how we choose to be seen. Clothes carry meaning, which is why we wear certain outfits in some contexts and not in others. So, when we explore the culture of the Indian sari, we must pay attention to its context, its variations, and its meaning for different members of Indian society." (The Sari: Meanings) [86]

Although there is no specific reference in the text to Supaya's living in India or in any other country, the title of Shakuntala Boolell's book, La femme enveloppée et autres nouvelles de Maurice, clearly tells us that the stories contained in the book are from the African Island of Maurice that shelters a large number of population with Indian ancestry. The only identity that remains clear, however, is that of an Indian woman in her sari and how the sari dignifies her in search of her identity, be it in India or the Indian diaspora. In her constant inner journey to find her identity, Supaya has made an art of her introspection and construction of her gendered self. The result of her artistic creation is manifest in the admiration she has aroused in other women who ask her: "Tell us, Supaya, you are too perfect a mannequin. What is your secret?" To what Supaya replies: "Perhaps the fact of having become aware of the short distance that exists between the sari and myself." And, certainly, as the narrator adds "Nobody could stand between her and her sari. Wearing it daily granted her an acute awareness of her identity." (195) [87].

\section{Conclusion}

Shakuntala Boollel's displays new feminist approaches to explain the life of Indian women especially in traditional locations. More specifically, the author examines the lives of Indian women in post-colonial contexts in which traditional oppressive rules persist and women are forced to obey them if they want to be accepted as members of their community. However, Boolell exposes old and oppressive meanings embedded in the ancient and emblematic Indian attire - the sari-and in the religious tradition of women's veiling. However, the author subverts those meaning to uncover new ones that the women themselves create in order to transcend 
their oppressive realities. Therefore, Boolell turns what from Western societies would be considered passive behaviour in women who seem resigned to accept those oppressive environments into women who become active creators of their own particular destinies using the same tools that were supposedly made to control and oppress them. Boolell displays new feminist readings that do not conform to Western feminist theories and thus remind us that every woman, no matter the context she is forced to live in, continues to subvert those conditions to maintain her dignity and inner freedom. Moreover, the writer illustrates that there are multiple readings to the also multiple traditions encountered in the vast worldwide range of cultures. She chooses the Indian sari to illustrate the complexity and richness embedded in each tradition when analyzing them in depth. Supaya, the protagonist of Boolell's story, is able to subvert the oppressive meaning embedded in a traditional garment and an ancient religion (supposedly Hindu) that have been manipulated under patriarchy to degrade and/or control women and find new meanings and attributes. The new meaning and attributes discovered by Supaya are used to her own service to transcend oppression and shape her identity.

\section{REFERENCES}

[1] V. Pereyra, L. M. Mora, eds. Las voces del arco iris: Textos femeninos y feministas al Sur del Sahara, Edotproañ Tanya. S. A., México, 2002.

[2] E. Tarlo. Clothing Matters: Dress and Identity in India, University of Chicago Press, Chicago, 1996.

[3] E. Tarlo. Clothing Matters: Dress and Identity in India, University of Chicago Press, Chicago, 1996.

[4] See N. Chaudhury. Culture in the Vanity Bag, Jaico, Bombay, 1976.

[5] E. Tarlo. Clothing Matters: Dress and Identity in India, University of Chicago Press, Chicago, 1996.

[6] E. Tarlo. Clothing Matters: Dress and Identity in India, University of Chicago Press, Chicago, 1996.

[7] V. Pereyra, L. M. Mora, eds. Las voces del arco iris: Textos femeninos y feministas al Sur del Sahara, Edotproañ Tanya. S. A., México, 2002.

[8] Gnaana, The Origin of the Sari, January 11, 2012. Online available

fromhttp://www.gnaana.com/blog/2012/01/the-origin-of-thesari/

[9] E. Tarlo. Clothing Matters: Dress and Identity in India, University of Chicago Press, Chicago, 1996.

[10] Sari History through the Ages, March 29, 2012. Online available http://www.fancy-indian-saris.com/sari-history.html

[11] R. Sami. The Origin and History of the Indian Sari, June 28,
2011. Online availablefromhttp://expertscolumn.com/conten t/origin-and-history-indian-sarihttp://expertscolumn.com/con tent/origin-and-history-indian-sari

[12] The Sari: Meanings behind the Cloth, June 28, 2011. Online available

fromhttp://factsfashion.wordpress.com/2011/06/28/the-sarimeanings-behind-the-cloth

[13] P. R. Ghosh. Western Women Should Not Wear the Indian Sari, February 2, 2012. Online available fromhttp://www.ibtimes.com/articles/293861/20120206/indi an-sari-fashion-western-women-bollywood.htm

[14] P. R. Ghosh. Western Women Should Not Wear the Indian Sari, February 2, 2012. Online available fromhttp://www.ibtimes.com/articles/293861/20120206/indi an-sari-fashion-western-women-bollywood.htm

[15] S. Boolell. "La mujer envuelta" (La femme enveloppée). In Las voces del arco iris: Textos femeninos y feministas del Sur del Sahara, ed. by V. Pereyra and L. M. Mora, Editorial Tanya, México, 2002. (This book incluyes includes the Spanish translation taken from La femme enveloppée et autres nouvelles de Maurice, 1996). All the quotations taken from this nouvelle have been translated from Spanish (only version available) into English by the author of this essay.

[16] Purdah and Rural Housing in South Asia: A Literature Review. Created June 4, 2011. Online available from http://www.mcgill.ca/mchg/student/segregation/chapter3

[17] E. Tarlo. Clothing Matters: Dress and Identity in India, University of Chicago Press, Chicago, 1996.

[18] E. Tarlo. Clothing Matters: Dress and Identity in India, University of Chicago Press, Chicago, 1996.

[19] E. Tarlo. Clothing Matters: Dress and Identity in India, University of Chicago Press, Chicago, 1996.

[20] E. Tarlo. Clothing Matters: Dress and Identity in India, University of Chicago Press, Chicago, 1996.

[21] E. Tarlo. Clothing Matters: Dress and Identity in India, University of Chicago Press, Chicago, 1996.

[22] E. Tarlo. Clothing Matters: Dress and Identity in India, University of Chicago Press, Chicago, 1996.

[23] S. Sahoo. Blog Questions of Sexual Politics in Indian Literature, April 26, 2012. Online available fromhttp://sarojinisahoo.blogspot.com.es

[24] Lifting the Veil: Women's Rights in India, April 16, 2012. Online available from http://www.haddonfield.k12.nj.us/hm hs/academics/english/Women'sRightsinIndia.htm

[25] Lifting the Veil: Women's Rights in India, April 16, 2012. Online availablefromhttp://www.haddonfield.k12.nj.us/hmhs/acade mics/english/Women'sRightsinIndia.htm

[26] E. Tarlo. Clothing Matters: Dress and Identity in India, University of Chicago Press, Chicago, 1996.

[27] E. Tarlo. Clothing Matters: Dress and Identity in India, University of Chicago Press, Chicago, 1996. Hanna Papanek in her essay "Purdah: Separate Worlds and Symbolic Shelter"(1973) also considers burqa and the sari to be garments that "enable women to move out of [the home]. As a 
result, and despite its forbidding appearance, the burqa can be considered a liberating invention and is seen in this way by many women themselves" (295). No doubt that, although a garment of confinement and repression for women, in the countries where women are forced to wear it, they are also probably protected by this garment from male sexual harassment. However, I personally do not think a parallel can be drawn between burqa and sari since the sari also might accentuate a woman's body and be a sensual and very elegant and colourful dress; whereas the burqa is a cloak, usually black or dark, that is worn on top of a woman's clothes and is made to hide the woman's body completely. Even the fabrics used for the sari are especially soft and light which helps the woman move more freely than the burqa, which, on the other hand, is made of a type of rougher fabric that really hinders women's freedom to move as well as her sight. Finally, the sari is worldwide accepted and not regarded as an instrument of women's oppression as it happens with the burqa (especially from Western countries). I also think that burqa and hijab cannot be compared either, since the hijab usually covers only a woman's head and her face can still be seen; furthermore, the hijab alone does not necessarily hinder women's moves. Nonetheless, the study of women's veiling could be the topic for another essay or even entire book. For further information see Falguni A. Seth, The Hijab and the Sari: The Strange and Sexy between Colonialism and Global Capitalism. Ann Arbor; MI: MPublihsing, University of Michigan Library, 2009.

[28] S. Wieringa. Introduction. In Sub-versive Women: Women's Movements in Africa, Asia, Latin America and the Caribbean, ed. by S. Wieringa, Zed Books, London, 1995.

[29] S. Wieringa. Introduction. In Sub-versive Women: Women's Movements in Africa, Asia, Latin America and the Caribbean, ed. by S. Wieringa, Zed Books, London, 1995.

[30] S. Wieringa. Introduction. In Sub-versive Women: Women's Movements in Africa, Asia, Latin America and the Caribbean, ed. by S. Wieringa, Zed Books, London, 1995.

[31] S. Wieringa. Introduction. In Sub-versive Women: Women's Movements in Africa, Asia, Latin America and the Caribbean, ed. by Saskia Wieringa, Zed Books, London, 1995.

[32] T. de Lauretis, ed. Feminist Studies Critical Studies, Indiana University Press, Bloomington, 1986.

[33] T. de Lauretis, ed. Feminist Studies Critical Studies, Indiana University Press, Bloomington, 1986, my emphasis.

[34] T. de Lauretis, ed. Feminist Studies Critical Studies, Indiana University Press, Bloomington, 1986.

[35] S. Wieringa. Introduction. In Sub-versive Women: Women's Movements in Africa, Asia, Latin America and the Caribbean, ed. by S. Wieringa, Zed Books, London, 1995.

[36] K. Bhasin and N. S. Khan. Feminism and its Relevance in South Asia, Kali for Women, New Delhi,1986.

[37] S. Wieringa, Saskia. Introduction. In Sub-versive Women: Women's Movements in Africa, Asia, Latin America and the Caribbean, ed. by Saskia Wieringa, Zed Books, London, 5, 1995.

[38] L. Lowen . Traditions Restrict Women's Rights, Discourage Female Sexuality. Feminism in India - Conversation with Indian Feminist Sarojini Sahoo, April 16, 2012. Online available fromhttp:/womensissues.about.com/od/feminismequalrights /a/FeminisminIndia.htm

[39] S. Boolell. "La mujer envuelta" (La femme enveloppée). In Las voces del arco iris: Textos femeninos y feministas del Sur del Sahara, ed. by V. Pereyra and L. M. Mora, Editorial Tanya, México, 2002.

[40] S. Boolell. "La mujer envuelta" (La femme enveloppée). In Las voces del arco iris: Textos femeninos y feministas del Sur del Sahara, ed. by V. Pereyra and L. M. Mora, Editorial Tanya, México, 2002.

[41] It seems that Hindu and Muslim populations in Mauritius come from the Indian subcontinent, and from the censuses of 1846 to 1952 were classified as Indo-Mauritians. The ancestral language of most Hindus is Hindi or Bhojpouri (there is also a minority of Tamil and Telegu speakers). Hindu carried with them the caste system although this system is not really important in social organization except for choosing spouses. Hindus observe their rituals mainly in rural areas. Muslims are approximately the 95 percent Sunni and Hindi-speaking. Other languages spoken are Bhojpuri, Gujarati, Urdu, and Arabic. Mauritius-Ethnicity, Religion, and Language, June 14, 2012. Online available fromhttp://www.mongabay.com/history/mauritius/mauritiusethnicity,_religion,_and_language.html

[42] S. Boolell. "La mujer envuelta" (La femme enveloppée). In Las voces del arco iris: Textos femeninos y feministas del Sur del Sahara, ed. by V. Pereyra and L. M. Mora, Editorial Tanya, México, 2002.

[43] S. Boolell. "La mujer envuelta" (La femme enveloppée). In Las voces del arco iris: Textos femeninos y feministas del Sur del Sahara, ed. by V. Pereyra and L. M. Mora, Editorial Tanya, México, 2002.

[44] S. Boolell. "La mujer envuelta" (La femme enveloppée). In Las voces del arco iris: Textos femeninos y feministas del Sur del Sahara, ed. by V. Pereyra and L. M. Mora, Editorial Tanya, México, 2002.

[45] S. Boolell. "La mujer envuelta" (La femme enveloppée). In Las voces del arco iris: Textos femeninos y feministas del Sur del Sahara, ed. by V. Pereyra and L. M. Mora, Editorial Tanya, México, 2002.

[46] S. Boolell. "La mujer envuelta" (La femme enveloppée). In Las voces del arco iris: Textos femeninos y feministas del Sur del Sahara, ed. by V. Pereyra and L. M. Mora, Editorial Tanya, México, 2002.

[47] E. Tarlo. Clothing Matters: Dress and Identity in India, University of Chicago Press, Chicago, 1996.

[48] S. Boolell. "La mujer envuelta" (La femme enveloppée). In Las voces del arco iris: Textos femeninos y feministas del Sur del Sahara, ed. by V. Pereyra and L. M. Mora, Editorial Tanya, México, 2002.

[49] S. Boolell. "La mujer envuelta" (La femme enveloppée). In Las voces del arco iris: Textos femeninos y feministas del Sur del Sahara, ed. by V. Pereyra and L. M. Mora, Editorial Tanya, México, 2002.

[50] S. Boolell. "La mujer envuelta" (La femme enveloppée). In Las voces del arco iris: Textos femeninos y feministas del Sur del Sahara, ed. by V. Pereyra and L. M. Mora, Editorial Tanya, México, 2002. 
[51] S. Boolell. "La mujer envuelta" (La femme enveloppée). In Las voces del arco iris: Textos femeninos y feministas del Sur del Sahara, ed. by V. Pereyra and L. M. Mora, Editorial Tanya, México, 2002.

[52] S. Boolell. "La mujer envuelta" (La femme enveloppée). In Las voces del arco iris: Textos femeninos y feministas del Sur del Sahara, ed. by V. Pereyra and L. M. Mora, Editorial Tanya, México, 2002.

[53] S. Boolell. "La mujer envuelta" (La femme enveloppée). In Las voces del arco iris: Textos femeninos y feministas del Sur del Sahara, ed. by V. Pereyra and L. M. Mora, Editorial Tanya, México, 2002.

[54] S. Boolell. "La mujer envuelta" (La femme enveloppée). In Las voces del arco iris: Textos femeninos y feministas del Sur del Sahara, ed. by V. Pereyra and L. M. Mora, Editorial Tanya, México, 2002.

[55] S. Boolell. "La mujer envuelta" (La femme enveloppée). In Las voces del arco iris: Textos femeninos y feministas del Sur del Sahara, ed. by V. Pereyra and L. M. Mora, Editorial Tanya, México, 2002.

[56] S. Boolell. "La mujer envuelta" (La femme enveloppée). In Las voces del arco iris: Textos femeninos y feministas del Sur del Sahara, ed. by V. Pereyra and L. M. Mora, Editorial Tanya, México, 2002.

[57] S. Boolell. "La mujer envuelta" (La femme enveloppée). In Las voces del arco iris: Textos femeninos y feministas del Sur del Sahara, ed. by V. Pereyra and L. M. Mora, Editorial Tanya, México, 2002.

[58] M. Cassou and S. Cubley. Life, Paint and Passion: Reclaiming the Magic of Spontaneous Expression, Jeremy P. Tarcher/Penguin Group (USA) Inc., New York, 1995.

[59] S. Wieringa. Introduction. In Sub-versive Women: Women's Movements in Africa, Asia, Latin America and the Caribbean, ed. by S. Wieringa, Zed Books, London, 1995.

[60] S. Wieringa. Introduction. In Sub-versive Women: Women's Movements in Africa, Asia, Latin America and the Caribbean, ed. by S. Wieringa, Zed Books, London, 1995.

[61] K. Bullock. Rethinking Muslim Women and the Veil: Challenging Historical and Modern Stereotypes, The International Institute of Islamic Thought, Herdon, VA, 2007.

[62] S. Boolell. "La mujer envuelta" (La femme enveloppée). In Las voces del arco iris: Textos femeninos y feministas del Sur del Sahara, ed. by V. Pereyra and L. M. Mora, Editorial Tanya, México, 2002.

[63] S. Boolell. "La mujer envuelta" (La femme enveloppée). In Las voces del arco iris: Textos femeninos y feministas del Sur del Sahara, ed. by V. Pereyra and L. M. Mora, Editorial Tanya, México, 2002.

[64] S. Boolell. "La mujer envuelta" (La femme enveloppée). In Las voces del arco iris: Textos femeninos y feministas del Sur del Sahara, ed. by V. Pereyra and L. M. Mora, Editorial Tanya, México, 2002.

[65] S. Boolell. "La mujer envuelta" (La femme enveloppée). In Las voces del arco iris: Textos femeninos y feministas del Sur del Sahara, ed. by V. Pereyra and L. M. Mora, Editorial Tanya, México, 2002.
[66] S. Boolell. "La mujer envuelta" (La femme enveloppée). In Las voces del arco iris: Textos femeninos y feministas del Sur del Sahara, ed. by V. Pereyra and L. M. Mora, Editorial Tanya, México, 2002.

[67] S. Boolell. "La mujer envuelta" (La femme enveloppée). In Las voces del arco iris: Textos femeninos y feministas del Sur del Sahara, ed. by V. Pereyra and L. M. Mora, Editorial Tanya, México, 2002.

[68] S. Wieringa. Introduction. In Sub-versive Women: Women's Movements in Africa, Asia, Latin America and the Caribbean, ed. by S. Wieringa, Zed Books, London, 1995.

[69] H. Papanek. "Purdah: Separate Worlds and Symbolic Shelter". Comparative Studies in Society and History, Vol. 15, No. 3, 289-325, June 1973

[70] S. Boolell. "La mujer envuelta" (La femme enveloppée). In Las voces del arco iris: Textos femeninos y feministas del Sur del Sahara, ed. by V. Pereyra and L. M. Mora, Editorial Tanya, México, 2002.

[71] S. Boolell. "La mujer envuelta" (La femme enveloppée). In Las voces del arco iris: Textos femeninos y feministas del Sur del Sahara, ed. by V. Pereyra and L. M. Mora, Editorial Tanya, México, 2002.

[72] S. Boolell. "La mujer envuelta" (La femme enveloppée). In Las voces del arco iris: Textos femeninos y feministas del Sur del Sahara, ed. by V. Pereyra and L. M. Mora, Editorial Tanya, México, 2002.

[73] E. Tarlo. Clothing Matters: Dress and Identity in India, University of Chicago Press, Chicago, 59, 1996.

[74] S. Boolell. "La mujer envuelta" (La femme enveloppée). In Las voces del arco iris: Textos femeninos y feministas del Sur del Sahara, ed. by V. Pereyra and L. M. Mora, Editorial Tanya, México, 2002.

[75] S. Boolell. "La mujer envuelta" (La femme enveloppée). In Las voces del arco iris: Textos femeninos y feministas del Sur del Sahara, ed. by V. Pereyra and L. M. Mora, Editorial Tanya, México, 2002.

[76] S. Boolell. "La mujer envuelta" (La femme enveloppée). In Las voces del arco iris: Textos femeninos y feministas del Sur del Sahara, ed. by V. Pereyra and L. M. Mora, Editorial Tanya, México, 2002.

[77] J. Cameron. The Artist's Way: A Spiritual Path to Higher Creativity, Jeremy P. Tarcher/Putnam, New York, 2002.

[78] S. Wieringa. Introduction. In Sub-versive Women: Women's Movements in Africa, Asia, Latin America and the Caribbean, ed. by S. Wieringa, Zed Books, London, 1995.

[79] S. Boolell. "La mujer envuelta" (La femme enveloppée). In Las voces del arco iris: Textos femeninos y feministas del Sur del Sahara, ed. by V. Pereyra and L. M. Mora, Editorial Tanya, México, 2002.

[80] S. Boolell. "La mujer envuelta" (La femme enveloppée). In Las voces del arco iris: Textos femeninos y feministas del Sur del Sahara, ed. by V. Pereyra and L. M. Mora, Editorial Tanya, México, 2002.

[81] The Sari: Mystery and Grace, April 29, 2012. Online available from http://www.buzzle.com/editorials/2-19-200450775.asp 
[82] Gnaana, The Origin of the Sari, January 11, 2012. Online available from http://www.gnaana.com/blog/2012/01/the-ori gin-of-the-sari. Two of the paintings by surrealist painter Remedios Varo (1908-1963), Embroidering Earth's Mantle (1961) The Fabric of Dreams (1935), clearly illustrate this myth.

[83] The term Kaurava is a Sanskrit term that means the descendants of Kuru, a legendary king who is the ancestor of many of the characters of the Mahabharata.

[84] R. Hoffman, Renee. Traditional Indian Wedding Saris, April 22, 2012. Online available fromhttp://www.ehow.com/about _6707737_traditional-indian-wedding-saris.html

[85] There are legends that collect this magical or metaphorical symbol of the cloth that never ended:Sari or sari like long dress is also mentioned in the world longest epic Mahabharata. The legend has it that when the Pandavas lost their wife Draupadi to the enemy clan in a gambling duel, the victors caught one end of her sari and continued to pull and unravel, but could reach no end. (Online available from http://www.fancy-indian-saris.com/sari-history.html)

[86] The Sari: Meanings Behind the Cloth, June 28, 2011. Online available

fromhttp://factsfashion.wordpress.com/2011/06/28/the-sarimeanings-behind-the-cloth

[87] S. Boolell. "La mujer envuelta" (La femme enveloppée). In Las voces del arco iris: Textos femeninos y feministas del Sur del Sahara, ed. by V. Pereyra and L. M. Mora, Editorial Tanya, México, 20. 